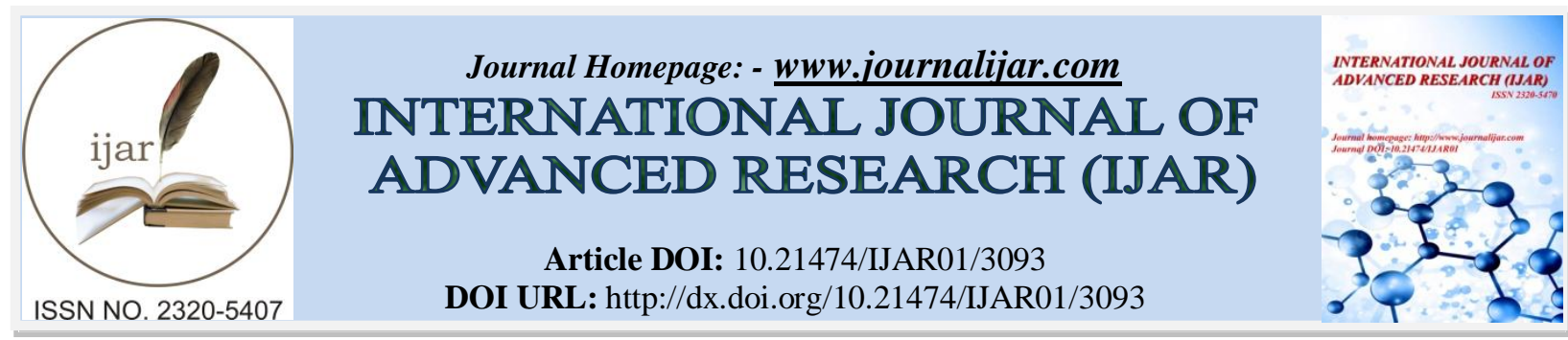

RESEARCH ARTICLE

\title{
"A STUDY ON THE STATISTICAL ESTIMATION OF URANIUM ION IN GROUNDWATER OF CUDDALORE DISTRICT, TAMILNADU, INDIA".
}

Paramaguru $P^{* 1}$., Anandhan $P^{2}$., Chidambaram $S^{3}$. Nepolian $\mathbf{M}^{1}$.and Devaraj $\mathbf{N}^{1}$.

1. Research Scholar, Department of Earth sciences, Annamalai University, Tamilnadu, India.

2. Assistant Professor, Department of Earth sciences, Annamalai University, Tamilnadu, India.

3. Professor, Department of Earth sciences, Annamalai University, Tamilnadu, India.

\section{Manuscript Info}

\section{Manuscript History}

Received: 03 November 2016

Final Accepted: 28 December 2016

Published: January 2017

Key words:-

Groundwater, GIS, Uranium, Spatial, Cuddalore, Statistics

\begin{abstract}
The present study aim to examine mapping of uranium distribution in the Cuddalore district, Tamil Nadu, India. Uranium is a relatively abundant element with the highest atomic number of all naturally occurring elements. The occurrences of groundwater are identified porous formation and in fractured and the weathered hard rock aquifer matrix. The geology of the district underline by different range of age from oldest Archean rocks to recent sediments. The study area occupy in 3,678 Sq.km. Totally 93 groundwater samples were collected during Pre- Monsoon, 2015. The collected samples were analyzed for major cations and anions in standard scientific manner. $\mathrm{U}$ was analyzed by using laser fluorimeter. The uranium concentration in the groundwater of this region ranges from $0.1 \mathrm{ppb}$ to $24.67 \mathrm{ppb}$ with an average of 1.82 $\mathrm{ppb}$. The analysis results shows the following order of dominance of ion $\mathrm{Cl}^{-}>\mathrm{H}_{4} \mathrm{SiO}_{4}>\mathrm{HCO}_{3}^{-}>\mathrm{NO}_{3}^{-}>\mathrm{Na}^{+}>\mathrm{Ca}^{2+}>\mathrm{Mg}^{2+}>\mathrm{K}^{+}>\mathrm{SO}_{4}{ }^{-}>\mathrm{F}^{-}>\mathrm{PO}_{4}^{-}$. It is inferred that most of the samples are fresh to slightly saline in nature. The spatial interpolation maps were prepared for demarcating the Uranium enriched region. Thus the regions with higher "U" concentration were delineated and the process responsible for the higher $\mathrm{U}$ was determined by statistical analysis.
\end{abstract}

Copy Right, IJAR, 2016,. All rights reserved.

\section{Introduction:-}

The groundwater chemistry is concern with a global perspective in groundwater Scenario. The hydrogeological characteristics and geochemicalassessment of the basin has been discussed by (Anandan et al.2010a, b, ; Ravi Kumar et al. 2010;Prasannaet al.2011). In this, Coastal aquifers constitute an important source of clean water supply, but are frequently faced with the problem of saltwater intrusion (Lenin et al., 2008). Uranium naturally occurs in three isotopic forms in soil, water, plants, animals and human beings. U-238 and U-235 are the parent nuclides of two independent decay series, while U-234 is a decay product of the U-238 series (Balvinder Singh et al., 2014). Uranium concentration in groundwater depends on several factors including lithological, geomorphologic and other geological conditions of the area (Sridhar-Babu MN, 2008). Uranium estimation of water systems of India has been reported by some authors likely Singh et al., 1984, 1995, 2001, 2002, 2008; Ramola et al., 1988; Sarin et al., 1992). Most of the uranium (upto $100 \mathrm{ppb}$ ) occurrences in groundwater in India are around the mining regions, uraniferrous conglomerates and around granitic intrusions. In Statistical methods use statistics to determine associations between spatial variables and actual occurrence of pollutants in the groundwater. Their 
limitations include insufficient water quality observations, data accuracy, and careful selection of spatial variables (Babiker et al. 2005).The estimation of uranium in water may be significant for the hydrogeochemical prospection and for health risk assessments. This study mainly focuson thespatial distribution of uranium and its behavior of groundwater, moreover an evaluate the geochemical process in the study area.

\section{Description of the study area:-}

\section{Study Area:-}

The area chosen for study in Cuddalore district, which falls in between South of the Ponnaiyar river and North of the Vellar River. It covers an area about 3,678 Sq.km, and lies between $15^{\circ} 5^{\prime \prime}$ and $12^{\circ} 35^{\prime \prime} \mathrm{N}, 78^{\circ} 38^{\prime \prime}$ and $80^{\circ} 00^{\prime \prime} \mathrm{E}$ it falls in Survey of India Map No: 56M/10, 14, 58M/11 and 15.(Fig1). The Significant role for East of Pichavaram Mangroves; south of Cuddalore port, SIPCOT Industries, followed by Colereon River flowing is there. Major part of the study area is devoted to agricultural activities, which include paddy, sugarcane, and groundnut and gingili cultivation. The geological reserves are Lignite, Limestone, White clay materials. In other important of Forest the total areas covered under the woodland in the district are 4171 lifts.

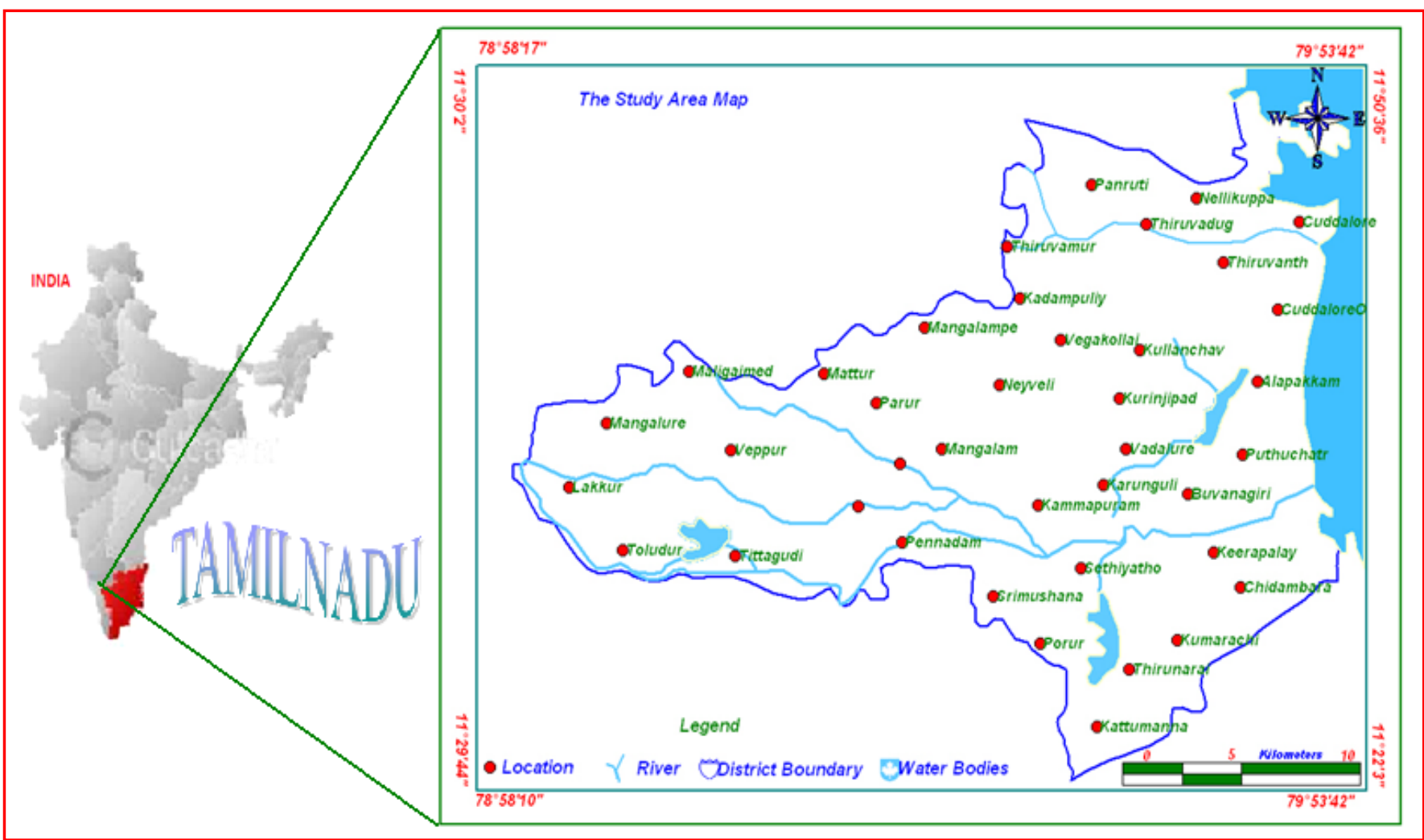

Fig 1:- Sampling Location map of the study area 


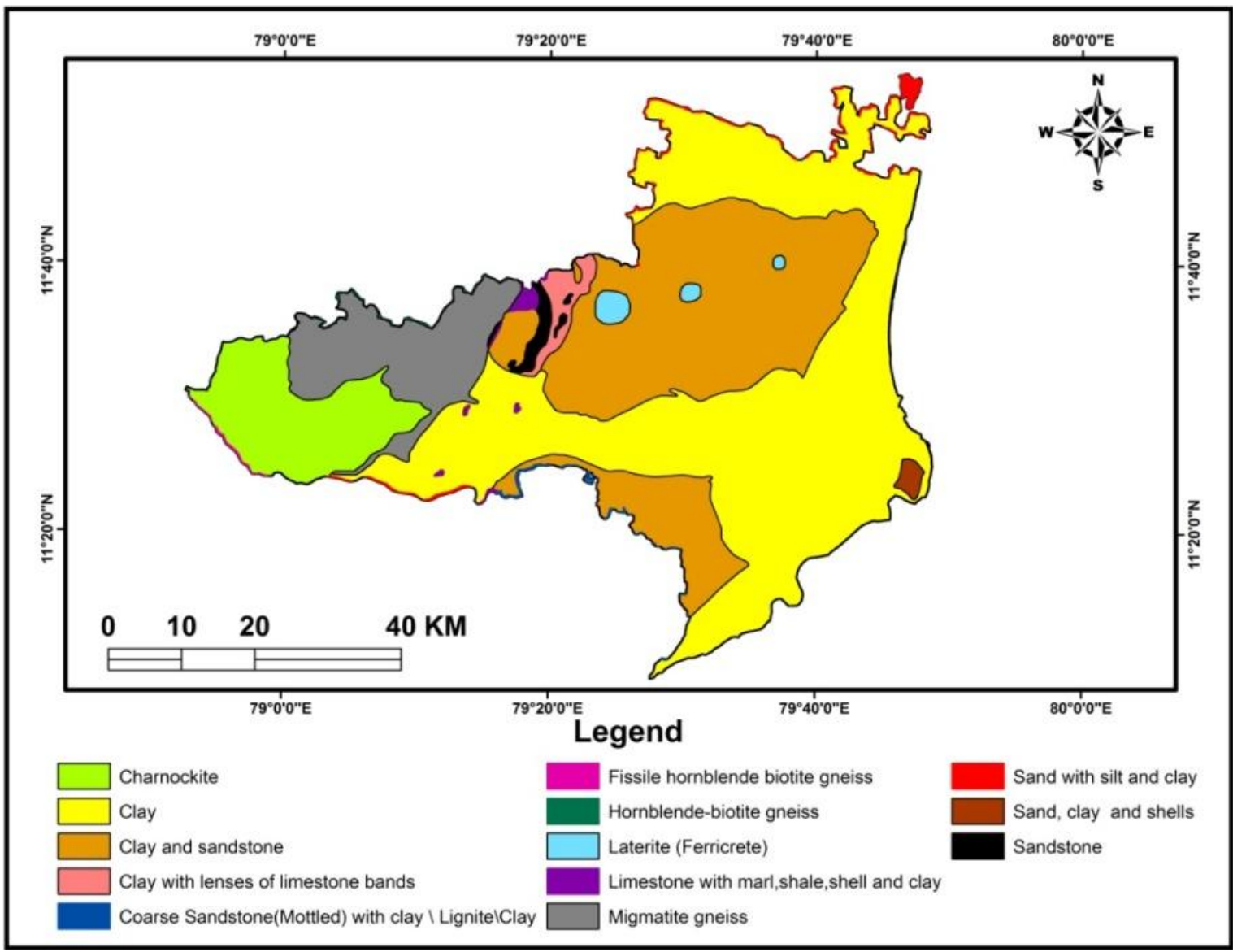

Fig 2:- Geology map of the study area

\section{Geology of the study area:-}

The geology of the area plays a significant role for assessing groundwater potential zone of the region. This district underline by different range of age from oldest Archean rocks to recent sediments. Tertiary and quaternary sedimentary rocks mainly make up the study area (Fig 2). The litho units represents mostly cover by Clay and Clay Sandstone in sedimentary formations and other than expose clay with lenses of limestone bands and bottom layer of coarse s.st with mottled clay with lignite, then small portion of cover by massive rock of Charnokite formation.

\section{Materials and Methods:-}

In total 93 samples of groundwater were taken into consideration collected from the study area pre-monsoon 2015.Samples were collected using polythene bottles washed with clear acid and standard procedures were used for analysis. The parameter, such as Temperature, $\mathrm{pH}$, EC (Electrical Conductivity) and TDS (Total Dissolved Solids were analyzed in Thermo Orion ion electrode probe Portable kit) were measured in the field. $\mathrm{Ca}^{2+}, \mathrm{Mg}^{2+}, \mathrm{HCO}_{3}{ }^{-} \mathrm{Cl}^{-}$, were analyzed in titrimetric Methods procedure adapting by (Ramesh, R.., Anbu, M.1996). $\mathrm{SO}_{4-}{ }^{2-}, \mathrm{PO}_{4}^{-}, \mathrm{H}_{4} \mathrm{SiO}_{4}$, and $\mathrm{NO}_{3}$ were determined by using UV Spectrophotometer $\mathrm{HACH} 6000$ Instrument. The analytical precision for the measurements of ions was determined by calculating the ionic balance error, which is generally within $\pm 5 \%$. The fluoride ions were analyzed in Thermo Orion ion electrode (F).The $\mathrm{Na}$ and $\mathrm{K}$ were analyzed in Flame photometer (Elico CL 378). The maps were prepared by Map info professional 8.5 and piper plot done by Aquachem4.0 . Calculation \& graphical representations were done by a computer program WATCLAST in C++ .

\section{Groundwater chemistry:-}

pH:-

The chemistry of groundwater samples studied about $\mathrm{pH}$ range between lowest for 5.59 maximum of 8.7 and with an average of 7.05 observed in the study area. A Water with a $\mathrm{pH}>8.5$ could indicate that the water is hard and acidic to alkaline in nature. The Hardness of the water results in aesthetic issues. 


\section{EC:-}

The Electrical conductivity (EC) values range from $95.7 \mu \mathrm{s} / \mathrm{cm}$ to $4890 \mu \mathrm{s} / \mathrm{cm}$ at $25^{\circ} \mathrm{C}$, averaging of about $1253 \mu \mathrm{s} / \mathrm{cm}$. The EC values reported in channels near location 27 are high \& inconsistent because of industrial discharge and urban waste disposition which results in leaching and accumulation of chemicals.

\section{TDS:-}

The total dissolved Solids were observed in maximum of $2410 \mathrm{ppm}$ to $50.1 \mathrm{ppm}$ in lowest with an average of 615 ppm in the study area. The cuddalore coastal region is generally occupied with alluvium soil. The study area is mostly covered by alluvial soil, because they having groundwater contain in very shallow depth. Some physical disturbance has been attempt it influence mining activities and under construction process, it cause the groundwater quality is suffered.

\section{Spatial Estimation of Uranium:-}

In this technique, on excitation of uranium complexes with UV light of $337.1 \mathrm{~nm}$ wavelength, the complexes emit green fluorescence that is measured by Photo Multiplier Tubes (PMT). Uranium concentration in aqueous samples is given by the measurement of fluorescence. The minimum detection limit (MDL) of the instrumentwas $0.2 \mathrm{lg} \mathrm{L}-1$. To avoid error due to different uranium complexes sodium pyrophosphate reagent wasused to convert various complexes into single form having same fluorescence yield (Sahoo SK, 2009). The spatial contribution of uranium is observed in higher concentration of $U$ is $>3.63 \mathrm{ppb}$, minimum of $1.35 \mathrm{ppb}$ with an average of 2.50 to $3.60 \mathrm{ppb}$. The majority of the samples fall in South side and Eastern part and rest of them is Western part of study area (Fig 3). In specifically, indicate that maximum range of $U$ is noted in the South margin and South west and north side is falls in moderate range and minimum concentration noted in towards East and small amount of western part. The obtained values and falling locations were identified in the contamination places and its describing the nature of geochemical behavior of groundwater.

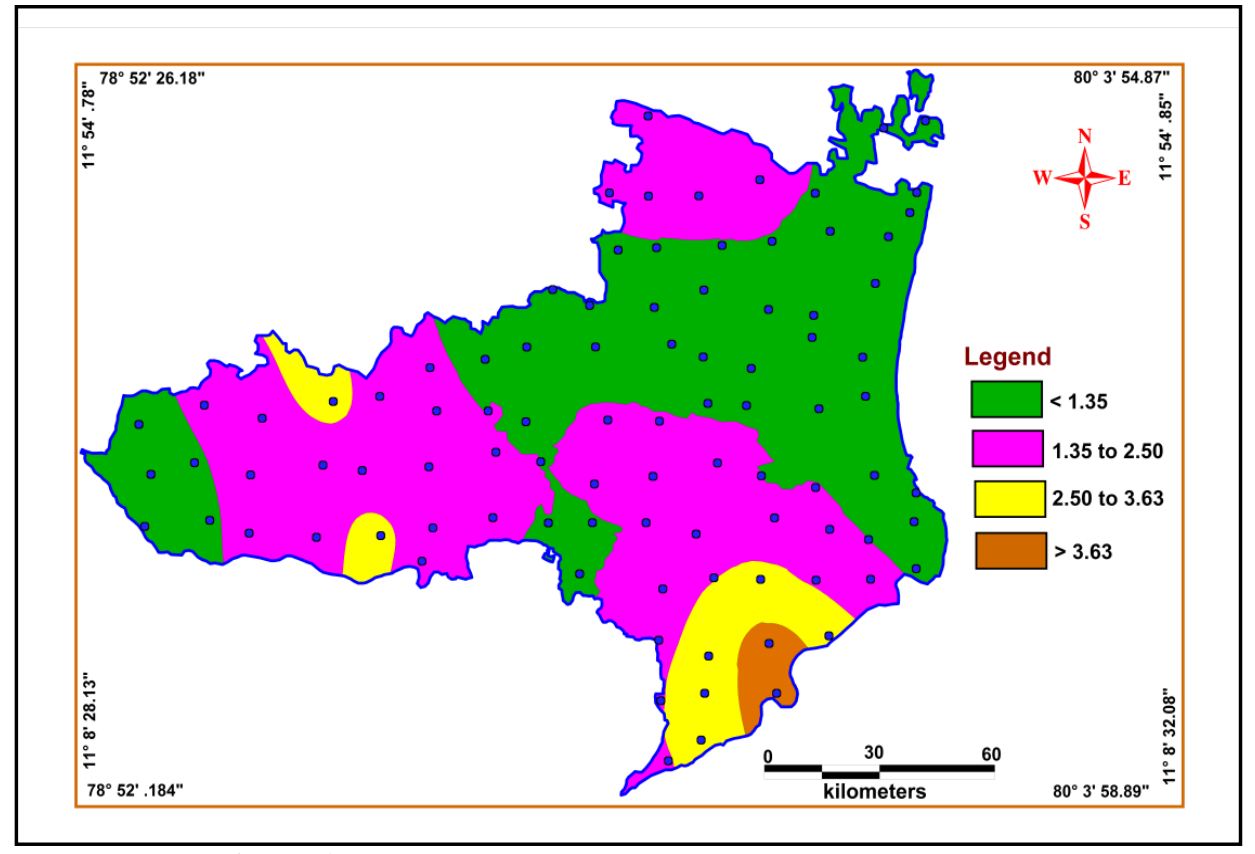

Figure 3:- Spatial distribution of Uranium in the study area

In specifically, indicate that maximum range of $U$ is noted in the South margin and South west and north side is falls in moderate range and minimum concentration noted in towards East and small amount of western part. The obtained values and falling locations were identified in the contamination places and its describing the in order to classify their saturation of geochemical contribution in the groundwater.

\section{Statistical Analysis:-}

\section{Correlation matrix:-}

The correlation matrix for groundwater samples collected from Cuddalore region is shown in (Table 1.1). Moderate correlation was observed between $\mathrm{pH}, \mathrm{HCO}_{3}{ }^{-}$and $\mathrm{Ca}, \mathrm{Mg}$ and $\mathrm{Cl}^{-}, \mathrm{Ca}^{+}$and $\mathrm{U}, \mathrm{Mg}$ and $\mathrm{Na}, \mathrm{Mg}$, and $\mathrm{Cl}, \mathrm{Mg}$ and 
good correlation of $\mathrm{Na}^{+}, \mathrm{Cl}^{-}$, and moderately correlate the $\mathrm{Na}, \mathrm{SO}_{4}{ }^{-}, \mathrm{U}, \mathrm{Na}^{+}$and $\mathrm{EC}, \mathrm{Na}$, TDS and Cl-, TDS and $\mathrm{EC}, \mathrm{HCO}_{3}{ }^{-}$and TDS, $\mathrm{SO}_{4}{ }^{-}$and $\mathrm{U}, \mathrm{EC}$ and TDS, $\mathrm{EC}$ indicating that all of them have the same origin (Chidambaram and Ramanathan 2000).

Table:- Correlation matrix of Groundwater sample from Cuddalore district

\begin{tabular}{|c|c|c|c|c|c|c|c|c|c|c|c|c|c|c|c|}
\hline & pH & $\mathrm{Ca}^{+}$ & $\mathbf{M g}^{+}$ & $\mathrm{Na}^{+}$ & $\mathbf{K}^{+}$ & $\mathrm{Cl}^{-}$ & $\begin{array}{c}\text { HCO } \\
3- \\
\end{array}$ & $\mathbf{F}^{-}$ & $\mathrm{NO}_{3}$ & $\begin{array}{c}\text { PO } \\
4 \\
\end{array}$ & $\mathrm{SO}_{4}$ & $\begin{array}{c}\mathrm{H}_{4} \mathrm{Sio} \\
4 \\
\end{array}$ & $\mathbf{U}$ & EC & $\begin{array}{c}\text { TD } \\
\text { S }\end{array}$ \\
\hline pH & 1 & & & & & & & & & & & & & & \\
\hline $\mathrm{Ca}^{+}$ & 0.06 & 1.00 & & & & & & & & & & & & & \\
\hline $\mathbf{M g}^{+}$ & 0.25 & 0.57 & 1.00 & & & & & & & & & & & & \\
\hline $\mathbf{N a}^{+}$ & 0.35 & 0.38 & \begin{tabular}{c|}
0.58 \\
\end{tabular} & 1.00 & & & & & & & & & & & \\
\hline $\mathbf{K}^{+}$ & 0.12 & 0.20 & 0.26 & 0.31 & 1.00 & & & & & & & & & & \\
\hline $\mathrm{Cl}^{-}$ & 0.09 & 0.71 & 0.74 & 0.80 & 0.38 & 1.00 & & & & & & & & & \\
\hline $\begin{array}{l}\text { HCO } \\
3-\end{array}$ & 0.63 & 0.21 & 0.42 & 0.41 & 0.00 & 0.10 & 1.00 & & & & & & & & \\
\hline $\mathbf{F}^{-}$ & 0.20 & $\begin{array}{c}- \\
0.24\end{array}$ & 0.02 & 0.17 & $\begin{array}{c}- \\
0.12 \\
\end{array}$ & $\begin{array}{c}- \\
0.13 \\
\end{array}$ & 0.38 & 1.00 & & & & & & & \\
\hline $\mathrm{NO}_{3}{ }^{-}$ & 0.08 & 0.03 & 0.14 & 0.12 & 0.11 & $\begin{array}{c}- \\
0.02\end{array}$ & 0.22 & 0.15 & 1.00 & & & & & & \\
\hline PO4 $^{-}$ & 0.02 & $\begin{array}{c}- \\
0.05 \\
\end{array}$ & $\begin{array}{c}- \\
0.14 \\
\end{array}$ & 0.06 & 0.54 & 0.00 & -0.02 & $\begin{array}{c}- \\
0.08\end{array}$ & 0.05 & 1.00 & & & & & \\
\hline $\mathrm{SO4}^{-}$ & 0.28 & 0.17 & 0.44 & 0.50 & 0.10 & 0.40 & 0.33 & 0.11 & $\begin{array}{c}- \\
0.02\end{array}$ & $\begin{array}{c}- \\
0.09\end{array}$ & $\begin{array}{c}1.0 \\
0\end{array}$ & & & & \\
\hline $\mathrm{H}_{4} \mathrm{Sio}$ & $\begin{array}{c}- \\
0.12\end{array}$ & 0.09 & $\begin{array}{c}- \\
0.07\end{array}$ & $\begin{array}{c}- \\
0.10\end{array}$ & $\begin{array}{c}- \\
0.09\end{array}$ & $\begin{array}{c}- \\
0.05\end{array}$ & -0.11 & $\begin{array}{c}- \\
0.01\end{array}$ & 0.33 & $\begin{array}{c}- \\
0.05\end{array}$ & $\begin{array}{c}0.0 \\
7\end{array}$ & 1.00 & & & \\
\hline $\mathbf{U}$ & 0.15 & 0.30 & 0.52 & 0.56 & 0.10 & 0.48 & 0.28 & 0.04 & 0.07 & $\begin{array}{c}- \\
0.03\end{array}$ & $\begin{array}{c}0.3 \\
2\end{array}$ & -0.08 & $\begin{array}{c}1.0 \\
0\end{array}$ & & \\
\hline Ec & 0.46 & 0.30 & 0.47 & 0.59 & 0.12 & 0.37 & 0.62 & 0.08 & 0.12 & 0.01 & $\begin{array}{c}0.4 \\
7 \\
\end{array}$ & -0.12 & $\begin{array}{c}0.5 \\
0 \\
\end{array}$ & $\begin{array}{c}1.0 \\
0 \\
\end{array}$ & \\
\hline TDS & 0.33 & 0.31 & 0.45 & 0.65 & 0.19 & 0.53 & 0.44 & 0.09 & 0.16 & 0.04 & $\begin{array}{c}0.5 \\
0\end{array}$ & 0.00 & $\begin{array}{c}0.4 \\
5\end{array}$ & $\begin{array}{c}0.6 \\
1 \\
\end{array}$ & $\begin{array}{c}1.0 \\
0\end{array}$ \\
\hline
\end{tabular}

PCA analysis and Factor Analysis:-

Statistical computations adopting a discrete method to point out the Principal component analysis (PCA) is a powerful tool that attempts to explain the variance of a large dataset of inter-correlated variables with a smaller set of independent variables (Simeonovet al. 2003). PCA technique extracts the Eigenvalues and eigenvectors from the covariance matrix of original variables. The Principal Components (PC) is the uncorrelated (orthogonal) variables obtained by multiplying the original correlated variables with the eigenvector, which is a list of coefficients (loadings or weightings).It includes loading for the rotated component matrix, eigen values for each component, per cent and cumulative per cent of variance explained by each component. It indicates that principal components together account for $\mathbf{6 6 . 1 2} \%$ of the total variance in the dataset, in which the first principal component is $\mathbf{2 9 . 2 \%}$, second principal component is $\mathbf{4 6 . 0 4 \%}$, and the third principal component is $57.05 \%$ \& fourth principal component is $66.1 \%$ of the total variance.

The Eigenvalues of the first three principal components $(>1)$ can be used to assess the dominant hydro geochemical processes. The concentrations of $\mathbf{C a}, \mathbf{M g}$, Na and Cl'show high positive loadings (0.75-0.95) whereas concentrations of EC, TDS, $\mathbf{S O}_{4}, \mathbf{N O}_{3}$ and $\mathbf{U}$ is the moderate positive loadings range between (0.50-0.75) and remaining of $\mathbf{p H}, \mathbf{K}^{+}, \mathbf{H C O}_{3}$, have low positive loadings (0.16-0.34), for the first principal component . 
Table 1.2:- Principal Component Analysis (Rotated Varimax)

\begin{tabular}{|l|c|c|c|c|}
\hline \multicolumn{5}{|c|}{ Rotated Component Matrix } \\
\hline & $\mathbf{1}$ & $\mathbf{2}$ & $\mathbf{3}$ & $\mathbf{4}$ \\
\cline { 2 - 5 } & .172 & .727 & .116 & -.104 \\
\hline $\mathrm{pH}$ & .577 & .570 & .055 & -.061 \\
\hline $\mathrm{TDS}$ & .650 & .401 & .110 & .088 \\
\hline $\mathrm{Ca}+$ & .746 & -.241 & .022 & .085 \\
\hline $\mathrm{Mg}+$ & .824 & .137 & -.017 & .022 \\
\hline $\mathrm{Na}+$ & .775 & .335 & .184 & -.025 \\
\hline $\mathrm{K}+$ & .266 & -.060 & .843 & .005 \\
\hline $\mathrm{Cl}-$ & .921 & -.154 & .157 & -.049 \\
\hline $\mathrm{HCO}$ & .809 & -.029 & .040 \\
\hline $\mathrm{F}-$ & .298 & .628 & -.147 & .133 \\
\hline $\mathrm{NO}_{3}$ & -.152 & .237 & .155 & .790 \\
\hline $\mathrm{PO}_{4}$ & .035 & .019 & .882 & .004 \\
\hline $\mathrm{SO}_{4}$ & -.127 & .336 & -.097 & .018 \\
\hline $\mathrm{H}_{4} \mathrm{SIO}_{4}$ & .546 & -.171 & -.135 & .826 \\
\hline $\mathrm{U}$ & -.002 & .186 & -.027 & -.048 \\
\hline Extraction Method: Principal Component Analysis. & & \\
$\mathrm{Rotation}_{4}$ & .652 & & \\
\hline
\end{tabular}

\section{Results and Discussion:-}

The groundwater vulnerability assessment is a critical point in decision-making processes, aiming to land use and resource management optimization. Therefore, it is imperative the adoption of preventive measures as well as accurate monitoring processes. Here, we discuss about the spatial distribution of these factors will permit the identification of potential pollution sources, taking into account the primary activities in the subject area: agriculture, mining, industrial or urban activities. Groundwater is unsuitable for domestic use in $2 \%$ of this area based on the limit of $60 \mathrm{ppb}$ prescribed by the AERB (Atomic Energy Regulatory Board of India). The reported that the concentration of uranium was relatively higherthan the USEPA drinking water limit of $30 \mathrm{ppb}$.

The concentration of uranium in groundwater greatly depends on the composition of the rocks in the aquifer. WHO, 2004 had recommended $15 \mathrm{ppb}$ of uranium in drinking water as safe limit. The (table1.3) shows that to understand the variability of uranium and also we can estimate the percentage of contaminate into the study area. Some anthropogenic activities like mining, milling, and nuclear fuel processing add uranium to various environmental components (EPA (2009). These values represent mostly covered $0.1 \mathrm{ppb}$ to $1.0 \mathrm{ppb}$ of 62 samples in $66.7 \%$ were found very mild rate of pollution. Then $1 \mathrm{ppb}$ to $2 \mathrm{ppb}$ of $11.8 \% 11$ samples denotes small range of pollution, and remaining, 5 samples represents $2 \mathrm{ppb}$ to $3 \mathrm{ppb} 5.40 \%$, 3ppb to $4 \mathrm{ppb}$ of 4 samples falls in $4.30 \%$, and others $4 \mathrm{ppb}$ to $5 \mathrm{ppb}$ in 3 samples are covers $3.22 \%$ \& $5 \mathrm{ppb}$ to $7 \mathrm{ppb}$ of $2.15 \%$ in 2 samples were found and In such that we can infer the very highest range of uranium concentration is observed that following range: $9 \mathrm{ppb}$ to $1.0 \mathrm{ppb}$ $1.07 \%$ of 1 sample and $2.15 \%$ sample are fall in $>10 \mathrm{ppb}$ range of concentration in the study area(table 1.4). The source of $\mathrm{u}$ has been carried the mining activity and some chemical solvents are dissolves in surface water as well as groundwater due can possible to have the uranium or uranyl particle in that water system. So these proportions are demarcating the variability of geochemical contribution of uranium in the present groundwater.

Table 1.3:- Shows different range of Uranium concentration in the Cuddalore region

\begin{tabular}{|c|c|c|c|}
\hline S.No & Country & Range of $U(\mu \mathrm{g} \cdot \mathrm{l}-1)$ & References \\
\hline 1 & Turkey & $0.24-17.65$ & Kumru at al. (1995) \\
\hline 2 & South Greenland & $0.5-1.0$ & Brown et al (1983) \\
\hline 3 & USA & $0.01-652$ & Cothern et al (1983) \\
\hline 4 & Kuwait & $0.02-2.48$ & Bou-Rabee et al (1995) \\
\hline 5 & Jordan & $0.04-1400$ & Smith et al (2000) \\
\hline 6 & Central Australia & $>20$ & Hostetler et al (1998) \\
\hline 7 & Cochin, India & $0.34-2.54$ & Prabhu R.S. et al (2008) \\
\hline 8 & Cuddalore district, India & 0.1 ppb 24.67 ppb & Present Study \\
\hline
\end{tabular}


Table 1.4:- Comparison of uranium concentration in drinking water in different countries

\begin{tabular}{|c|c|c|}
\hline S.No & Conc. Range (ppb) & Percentage of "U " \\
\hline 1 & $<1.0$ & $66.70 \%$ \\
\hline 2 & $1-2$ & $11.82 \%$ \\
\hline 3 & $2-3$ & $5.40 \%$ \\
\hline 4 & $3-4$ & $4.30 \%$ \\
\hline 5 & $4-5$ & $3.22 \%$ \\
\hline 6 & $5-6$ & $2.15 \%$ \\
\hline 7 & $6-7$ & $2.15 \%$ \\
\hline 8 & $9-10$ & $1.07 \%$ \\
\hline 9 & $>10$ & $2.15 \%$ \\
\hline
\end{tabular}

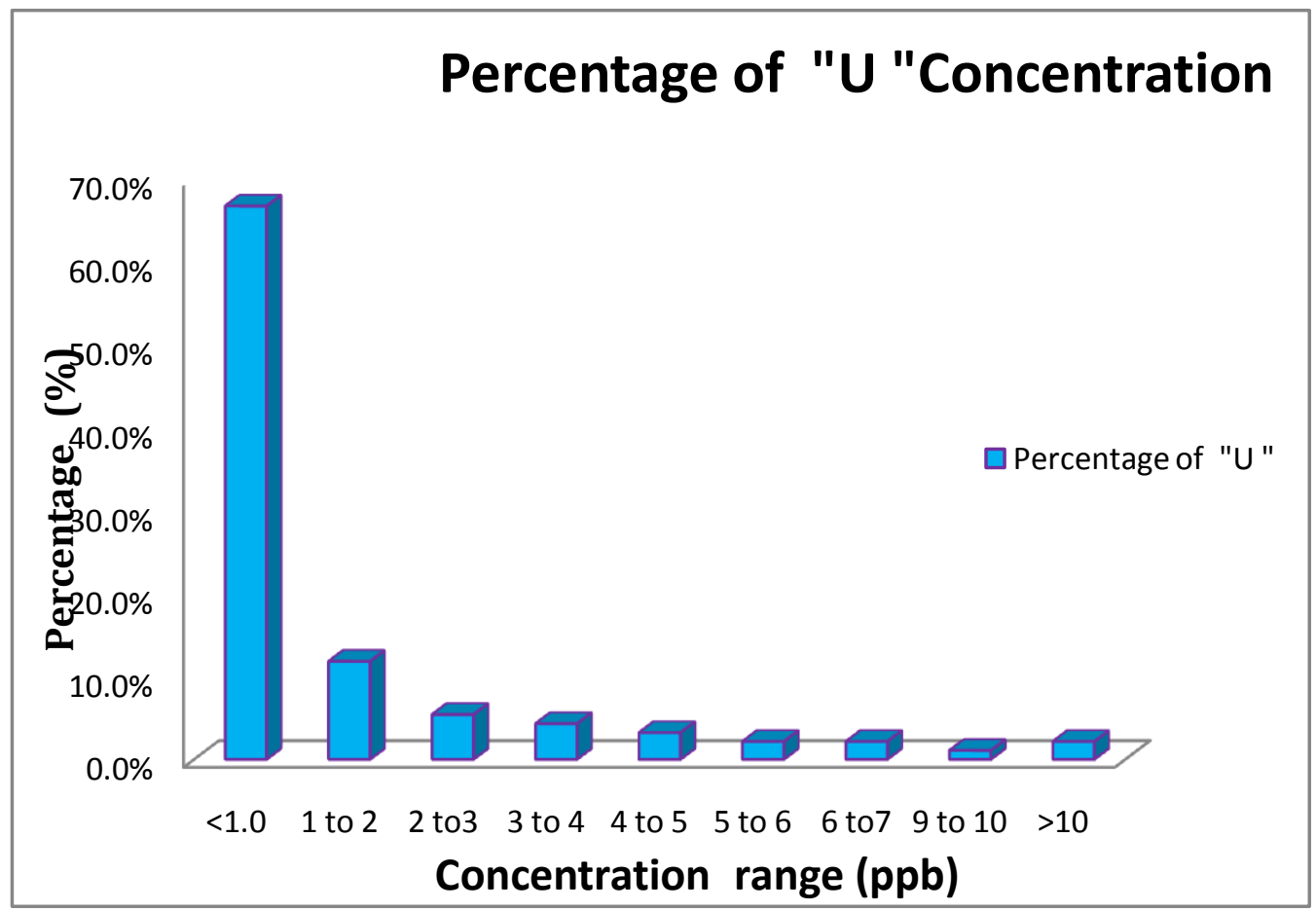

Fig. 4:- Vertical proportion of uranium percentage in groundwater in the cuddalore region during pre-monsoon.

The above chart is representing the concentration of uranium ion presence of cuddalore area denotes the visual observation of higher range of $66.70 \%$ of samples in fall $<1.0 \mathrm{ppb}$, medium level of $1-2 \mathrm{ppb}$ in $11.82 \%$, rest of the samples are falls in 2-3 ppb in 5.4\%, and other samples were found in 3-4 ppb to $>10.0 \mathrm{ppb}$ in minor distribution for this study area.

\section{Conclusion:-}

The present study is conclude that majority of the samples were indicatesthe not affected in uranium contaminant, only few samples were found in higher concentration. Then, it is calculating by their spatial volume of uranium content. The obtained results shows the following order of dominance of ion $\mathrm{Cl}^{-}>\mathrm{H}_{4} \mathrm{SiO}_{4}>\mathrm{HCO}_{3}>\mathrm{NO}_{3}>$ $\mathrm{Na}^{+}>\mathrm{Ca}^{2+}>\mathrm{Mg}^{2+}>\mathrm{K}^{+}>\mathrm{SO}_{4}^{-}>\mathrm{F}^{-}>\mathrm{PO}_{4}^{-}$. It is inferred that most of the samples are fresh to slightly saline in nature. The Uranium spatialmap was studied to estimate the volume and their saturation points were found. These distributions of samples are covered in Majority samples were fall in South side and Eastern part and rest of them is Western part of study area. In which, overall water geochemistry results reflects to support the human utility. The graphical value indicates the each location proportion of uranium ionindividual rating ofstudy status. The area denotes the visual observation of higher range of $66.70 \%$ of samples in fall $<1.0 \mathrm{ppb}$, medium level of $1-2 \mathrm{ppb}$ in $11.82 \%$, rest of 
the samples are falls in 2-3 ppb in 5.4\%, and other samples were found in 3-4 ppb to $>10.0 \mathrm{ppb}$ in minor distribution. Hence, the statistical approach insist correlate uranium ion with other geochemical parameters denotes the agricultural and artificial activities additionally mining manmade factors are influenced by to enrich the uranium distribution of groundwater in the Cuddalore region.

\section{References:-}

1. AERB, Directive for Limit on Uranium in Drinking Water, India. Mumbai: Atomic Energy Regulatory Board, 2004.

2. Anandan K.S, Sahay S.N, Karthikeyan (2010b) Delineation of recharge area and artificial recharge studies in the Neyveli Hydrogeological Basin. Mine Water Environment 29: 14- 22.

3. Anandhan K.S, Sahay S.N, Ramabadran T.K, Shiv Prasad S (2010a) Groundwater control techniques for safe exploitation of the Neyveli Lignite deposit, Cuddalore District, Tamilnadu, India. Mine Water Environment 29: 3-13.

4. Balvinder Singh V. K. Garg, Poonam Yadav, Nawal Kishore ,Vandana Pulhani (2014) Uranium in groundwater from Western Haryana, India, Journal of Radioanalytical and Nuclear Chemistry, Volume 301, Issue 2, pp 427-433.

5. Brown, A. Steenfelt, H. Kunzzenorf (1983)Uranium districts defined by reconnaissance geochemistry in South Greenland, Journal of Geochemical Exploration, 19 (1983), pp. 127-145

6. Chidambaram S., Ramanathan AL., Prasanna M.V., Karmegam U., Dheivanayagi V., Ramesh R., Johnsonbabu G., Premchander B. and Manikandan S. (2010). Study on the hydrogeochemical characteristics in groundwater, post-and pre-tsunami scenario, from Portnova to Pumpuhar, southeast coast of India. Environ Monit Assess $169,553-568$.

7. Chidambaram, S. Hydrogeochemical studies of groundwater in Periyar district, Tamilnadu, India, unpublished $\mathrm{Ph} . \mathrm{D}$ thesis, Department of Geology, Annamalai University. 2000

8. Chidambaram, S., Ramanathan, A.L., Prasanna, M.V., Loganatan, D., Badrinarayanan, T. S., Srinivasamoorthy, K., and Anandhan, P. (2008) Study on the impact of tsunami on shallow groundwater from portnova to pumpuhar, using geoelectrical technique - south east coast of India. Indian Journal of Marine Sciences, 37(2), pp.121-131.

9. Cothern, C. R.; Lappenbusch, W. L. Occurrence of uranium in drinking water in the United States. Health Phys. 1983, 45 (1), 89-99.

10. F. Bou-Rabee (1995) Estimating the concentration of uranium in some environmental samples in Kuwait after the 1991 Gulf War,AppliedRadiat Isotopes, 46 (1995), pp. 217-220.

11. Hostetler S, Wischusen J, Jacobson G (1998). Groundwater quality in the Papunya-Kintore region, Northern Territory. Australian Geological Survey Organisation, Canberra.

12. Kumru, M.N., (1995) Distribution of radionuclides in sediments and soils along the Buyuk Menderes River. Proc. Pakistan Acad. Sci., 32, p 51-56

13. Lenin KalyanaSundaram V., (2008) Vulnerability Assessment of Seawater Intrusion and Effect of Artificial Recharge in Pondicherry Coastal Region using GIS. Indian Journal of Science and Technology. 1 (7) 1-7.

14. Prasanna M.V., Chidambaram S., Senthil Kumar G., Ramanathan A.L., and Nainwal H.C. (2011) Hydrogeochemical assessment of groundwater in Neyveli Basin, Cuddalore District, South India [J]. Arabian Journal of Geosciences. 4, 319-330.

15. R. S. Prabhu, R. Sathyapriya, S. K. Sahoo and S. Mahapatra, "Ingestion Dose Due to Natural Uranium to the Public through Drinking Water Pathways in Two Districts of Keral," Proceedings of 16th National Symposium on Environment, Hisar, 2008, pp. 551-555.

16. Ramesh, R., and Anbu, M. (1996). Chemical methods for environmental analysis- water and sediments, pp.161.

17. Ramola, R. C., Singh, S., \& Virk, H. S. (1988). Uranium and radon estimation in some water samples from Himalayas. Part D. Nuclear Tracks and Radiation Measurements, 15(1e4), 791-793.

18. Ravi Kumar V, Sahay S.N, Periasamy, Shiv Prasad, Karthikeyan S (2010) Groundwater basin management at the Neyveli Lignite Mines. Mine Water Environment 29: 23-28.

19. Sahoo, S. K., Mohapatra, S., Chakrabarty, A., Sumesh, C. G., Jha, V. N., Tripathi, R. M., \&Puranik, V. D. (2009). Distribution of uranium in drinking water and associated age-dependent radiation dose in India. Radiation protection dosimetry,136(2), 108-113.

20. Sarin M M, Krishnaswami S, Sharma K K and Trivedi J R (1992) Uranium isotopes and radium in the Bhagirathi- Alaknanda river system: Evidence for high uranium mobilization in the Himalaya; Curr. Sci. 62(12) 801-805. 
21. Simeonov V, Stratis JA, Samara C, Zachariadis G, Voutsa D, Anthemidis A, Sofoniou M, Kouimtzis T (2003) Assessment of surface water quality in northern Greece. Water Res 37:4119-4124

22. Singh J, Singh H, Singh S, Bajwa BS.(2008) Estimation of uranium and radon concentration in some drinking water samples. Radiat. Meas 43(Supplement 1):523-526.

23. Singh J, Singh L and Singh G (1995) High U-contents observed in some drinking waters of Punjab, India; J. Environ. Radioact. 26 217-222.

24. Singh R V, Sinha R M, Bisht B S and Banerjee D C (2002) Hydrogeochemical exploration for unconformity related uranium mineralization: Example from Palnadu sub-basin Cuddapah Basin, Andhra Pradesh, India; J. Geochem. Explor. 76 71-92.

25. Singh, N. F., Singh, M., Singh, S., \& Virk, H. S. (1984). Uranium and radon estimation in water and plants using SSNTD. Nuclear Tracks and Radiation Measurements, 8(1-4), 483-486.

26. Singh, S., Malhotra, R., Kumar, J., Singh, B., \& Singh, L.(2001). Uranium analysis of geological samples, water and plants from Kulu Area, Himachal Pradesh, India. Radiation Measurements, 34, 427-431.

27. Smith B, Powell AE, Milodowski AE, Hards VL, Hutchins MG, Amro A, Gedeon R, Kilani S, Scrivens SM, Galt V (2000). Identification, investigation and remediation of ground water containing elevated levels of uranium-series radionuclides: a case study from the Eastern Mediterranean. In: Panayides L, Xenophotons C, Malpas J, (Eds.), Proceedings of the Third International Conference on the Geology of the Eastern Mediterranean, Nicosia, Cyprus. World Health Organization, Geneva (WHO/SDE/PHE/01.01).

28. World Health Organization, 2004. Guidelines for Drinking-water Quality: Summary Statement, 3rd ed., Geneva, WHO. 